\title{
Kirkelig uenighetsfellesskap
}

\section{Et bidrag fra agonistisk teologi til ekklesiologisk refleksjon}

\author{
Av Sven Thore Kloster
}

Trykt i Kirke og Kultur (Universitetsforlaget), 4/2020 årgang 125, s. 381-396.

Vitenskapelig publikasjon / DOI: https://doi.org/10.18261/issn.1504-3002-2020-04-09

English summary: The article discusses contributions from agonistic theology to contemporary ecclesiology. By drawing on well-known cases about conflicts regarding same sex marriage in the Church of Norway and the Anglican Communion, as well as the ecumenical discourse on unity, the article seeks to show how one can think of the church as a community of disagreement in light of the ecclesiological marks of unity, holiness, catholicity, and apostolicity.

Keywords: Ecclesiology, agonistic theology, same sex marriage, unity

Ingress: Kristendom er i stadig forandring. Men nye fortolkninger og praksiser oppstår ikke av seg selv. De skyldes meningsbrytninger og kamper om fortolkningshegemoni. Hvis kirken er et uenighetsfellesskap, hvordan forstår vi den da som én hellig, katolsk og apostolisk kirke?

Klassisk ekklesiologi, læren om kirken, tar utgangspunkt i kirkens fire vesensbestemmelser (esse), slik disse er formulert i de oldkirkelige trosbekjennelsene: Kirken er én hellig, katolsk og apostolisk kirke. Hvordan disse fire kategoriene skal forstås, har vært gjenstand for mye teologisk debatt. De er både beskrivende predikater til kirken og imperativer - en forpliktelse og oppgave for kirken i dens historiske eksistens. Selv om de fortolkes ulikt, blir ofte ekklesiologiske tekster strukturert etter disse.

Utgangspunktet mitt er tanken om, og erfaringen av, at kristne fortolkningsfellesskap er uenighetsfellesskap. Dette er en posisjon jeg har utviklet i min ph.d.-avhandling, og som jeg kaller for «agonistisk teologi». ${ }^{1}$ Formålet med denne artikkelen er å argumentere for hvordan agonistisk teologi kan bidra konstruktivt til ekklesiologisk forståelse. For hvordan kan en tenke om konflikt og uenighet i kirkelig sammenheng? Hvis kirken er et uenighetsfellesskap, hvordan kan vi da forstå den som én hellig, katolsk og apostolisk kirke? 


\section{Agonistisk teologi - hva er det?}

Ordet «agonistisk» er utledet fra det greske ordet agōn, som kan bety kamp eller konflikt. Men til forskjell fra begrepet «antagonistisk», som heller i retning av fiendtlig konflikt, brukes begrepet «agonistisk» i politisk filosofi om en ikke-voldelig kamp mellom motstandere som respekterer hverandre som legitime deltakere i et samfunn. ${ }^{2}$ Med agonistisk teologi mener jeg derfor en konfliktorient, ikke-voldelig teologi som vektlegger uenighet, og hvor deltakerne respekterer hverandre som legitime meningsmotstandere.

En kan forstå enkelte typer frigjøringsteologier eller «public theologies» som agonistiske teologier. Kirken eller kristne forstås da som en av flere grupper i et pluralistisk samfunn hvor de kjemper for sine politiske standpunkter og verdier, for eksempel sosial og økonomisk rettferdighet. ${ }^{3}$ Slike teologier er åpenbart viktige, men det er ikke dem jeg sikter til når jeg bruker begrepet agonistisk teologi. Den agonistiske teologien jeg foreslår, er en teologi som har som premiss at kristne fellesskap ikke er homogene, verken politisk eller teologisk. Konflikten forstås derfor primært som intern. Den finnes innenfor det kristne fellesskapet, kirken eller konfesjonen. Agonistisk teologi ser det kristne fellesskapet som et konfliktfylt fellesskap, et uenighetsfellesskap. ${ }^{4}$

Hvorfor er uenighet viktig? Først og fremst på grunn av fortolkningsåpenhet. Teologi er en praksis som beskjeftiger seg med mange av menneskers store, eksistensielle og evige spørsmål. Svarene, derimot, er ikke evige, men omstridte og historiske. Teologiske symboler og fortolkninger er gjenstand for uenighet og fortolkningsfeider. På den måten er uenighet både produktivt og formativt for kristen tradisjon: Kristen lære, for eksempel, springer ut av, men traderer også videre, bestemte konfliktlinjer. ${ }^{5}$ Eller for å si det med Alasdair McIntyre: «[W]hat constitutes a tradition is a conflict of interpretation of that tradition, a conflict which itself has a history of rival interpretations.» ${ }^{6}$ Gitt et slikt kulturelt utgangspunkt er hovedargumentet mitt at fortolkningsåpenhet er best ivaretatt når et mangfold av ulike og rivaliserende synspunkter blir artikulert, og ikke når en bestreber seg på konsensussøkende prosesser. Uenighet kan nemlig utvide fortolkningsrommet og forhindre at det stagnerer. Med andre ord er ikke teologiske påstander og sannhetskrav nødvendigvis trusler mot fortolkningsmangfoldet og -åpenheten, men snarere forutsetninger for dem. Uten uenighet og et mangfold av motstridende stemmer som forsøker å fortolke hva kristen tro betyr i en spesifikk kontekst, risikerer den teologiske refleksjonen og engasjementet å ebbe ut. For å 
opprettholde åpenhet og hindre fortolkningsrommet $\mathrm{i}$ å falle sammen må noen fylle det med konkrete fortolkninger. Samtidig må deltakerne finne seg i at en fortolkning, uansett hvor proklamerende den måtte være, alltid vil være én av flere mulige, og dermed også omstridt og midlertidig.

Den typen agonistisk teologi jeg har tatt til orde for, er dels inspirert av jødisk talmudisk tradisjon. ${ }^{7}$ Derfor hevder jeg at der hvor det er to kristne, bør det være minst tre ulike fortolkninger. Den er også dels inspirert av radikalt demokrati og den belgiske demokratiteoretikeren Chantal Mouffe, som blant annet kritiserer Habermas' fornuftsorienterte kommunikative teori og idé om idealdiskurs. ${ }^{8}$ Den er også inspirert av den amerikanske teologen Kathryn Tanner, som beskriver kristent fellesskap som «a community of argument», hvor kristne fortolkninger av virkeligheten ikke er gitt, men hele tiden forhandles og kjempes om. ${ }^{9}$ For Tanner er det viktig å synliggjøre hvem som har makt til å foreta teologiske valg og beslutninger, hva som har autoritet, og hvordan de ulike orienteringspunktene for liv og trospraksis skal identifiseres og vektlegges.

Jeg utdyper ikke det teoretiske rammeverket for agonistisk teologi videre i denne artikkelen. Det er gjort andre steder. ${ }^{10}$ Jeg skal heller bruke plassen til å diskutere tre ulike caser for å vise hvordan agonistisk teologi konkret kan bidra til ekklesiologisk tenkning. Jeg starter med å se på kampen for homofiles rettigheter og likekjønnet ekteskap i Den norske kirke. Så zoomer jeg ut og ser på uenigheten knyttet til homofilt samliv i det globale anglikanske kirkefellesskapet. Til sist utvider jeg perspektivet enda mer og ser på enhetsdiskursen i den $\emptyset$ kumeniske bevegelsen, hovedsakelig i Kirkenes Verdensråd. På den måten får jeg testet nytteverdien av agonistisk teologi på tre ulike typer kirkefellesskap, og i saker hvor konfliktlinjene både er av etisk og teologisk art. Alle tre casene er offentlig kjente saker om konflikter i ulike typer kirkefellesskap, og jeg baserer den deskriptive framstillingen av casene på andres observasjoner. Denne artikkelen er med andre ord ikke en empirisk casestudie. Jeg tolker de allerede kjente sakene fra et agonistisk-teologisk perspektiv for å se hva de kan kaste av seg i ekklesiologisk sammenheng. Dette innebærer også at jeg ikke fremmer en universell påstand om at uenighet og fortolkningskonflikt alltid og i alle situasjoner er produktivt og oppbyggelig, men jeg argumenterer for hvordan uenighet kan fungere som en ekklesiologisk ressurs i tre konkrete sammenhenger. Jeg bruker her agonistisk teologi dels som et analytisk perspektiv og dels som et normativt argument. Det betyr at jeg analyserer de ulike casene med et oppmerksomt blikk for agonistisk uenighet, samtidig som jeg forsøker å argumentere for hvordan agonistisk uenighet kan fortolkes som noe positivt i de aktuelle casene. 


\section{Homokampen i Den norske kirke}

Jeg starter med konflikten som kanskje mer enn noen har preget Den norske kirke de siste tiårene. Etter flere år med stridigheter og uenighet åpnet Kirkemøtet for Den norske kirke i 2007 opp for å ordinere homofilt samlevende prester, og i 2016 vedtok Kirkemøtet at det skulle utarbeides vigselsliturgier som inkluderer likekjønnede par. Det er åpenbart at konflikten var nødvendig for å få til endring i kirkelig lære og praksis. Slike endringer kommer ikke av seg selv. Hvordan kan agonistisk teologi bidra til å fortolke denne konflikten?

Et viktig moment er forholdet mellom tradisjon og hegemoni. Jeg tror at alle som deltok i kampen om homofiles rettigheter i Den norske kirke, erfarte at det var en hegemonisk kamp, som blant annet dreiet seg om å få definere hvem som er kirke, og hva som er kirkens budskap. At teologiske fortolkningskonflikter også er hegemoniske konflikter, det vil si konflikter mellom ulike sannhetshegemonier, utfordrer hvordan en tenker teologisk om tradisjon og apostolisitet. På et punkt i historien var ett parti eller én gruppe i posisjon til å forandre Den norske kirkes offisielle lære om homofilt samliv. Deres fortolkning av ekteskap, samliv og bibelsk autoritet ble forklart og legitimert ved å vise til et utvalg av bibelsteder, menneskelige erfaringer, verdier, livsfortolkninger og kirkelige læretradisjoner. Og disse forklaringene ble anerkjent som legitime og rimelige av et flertall av Kirkemøtets medlemmer. På denne måten tydeliggjorde konflikten at kirkelig tradisjon, forstått normativt, ikke er objektiv empiri, men hegemonisk diskurs. Å påberope seg tradisjon og kontinuitet verken beviser eller motbeviser hvorvidt en ny fortolkning er teologisk adekvat. Som Kathryn Tanner påpeker: Hvorvidt en ny fortolkning ser ut til å være i kontinuitet og overensstemmelse med fortiden, avhenger av hvilke deler av fortiden som settes sammen, og hvordan disse settes sammen - kort sagt hvordan fortiden representeres. ${ }^{11}$

Kontinuitet er derfor en tilskrevet kvalitet, og påstander om kontinuitet sier ofte mer om nåtidige behov enn om fortiden. Med Foucault kan vi si at historieskriving og tradisjonskonstruksjon i ytterste konsekvens er dypt politiske virksomheter. ${ }^{12}$ Dette betyr imidlertid ikke at konstruksjoner og påberopelse av kontinuitet ikke er viktig, eller at en kan forvente å få gehør for de mest utradisjonelle ideer som tenkes kan. Påstått kontinuitet med apostlenes lære, kristne fortellinger eller annen autoritativ fortid som en mener er vesentlig for kristen lære og identitet, må selvsagt artikuleres og forsvares godt hvis en ønsker å legitimere 
og få støtte for nye synspunkter. Nye fortolkninger må på en eller annen måte gjenkjennes som kristne for å få tilslutning. Eller som den danske teologen Niels Henrik Gregersen har formulert det: «Kun den teolog får kirkelig og kulturell betydning, som formår at nyformulere kristendommen på en måde, så det giver mening for det kristne sprogs brukere.» ${ }^{13}$

Selv om mange vil hevde at konflikten om homofiles rettigheter i Den norske kirke har vært vanskelig og utmattende, så kan en også hevde at den har vært med på å fornye, reformulere og utvide kristen tradisjon. Den har fått mange mennesker til å spørre seg selv: Hva betyr evangeliet, Guds kjærlighet, Den hellige ånds virke eller Luthers syn på ekteskapet i dag? Konflikten har fått folk til å spørre seg om hvem som er kirken, og hvilke deler av fortiden en erfarer som normativ og vil ta med seg framover. På den måten har konflikten fått folk til å diskutere spørsmål om apostolisitet. Og det skjer ikke hver dag i folkekirken.

Selv om mange var lei av konflikten, førte uenigheten også til at mange ble engasjert i kirken og i kirkepolitikk. Mer engasjement er nemlig noe av det konflikt og uenighet kan føre til. I 2005 var det om lag fire prosent av kirkemedlemmene som stemte ved valget til menighetsog bispedømmeråd. I 2015, året da vigselsliturgi for likekjønnede par ble aksjonert for og imot av henholdsvis de kirkepolitiske partiene Åpen folkekirke og Levende folkekirke, firedoblet valgdeltakelsen seg - til $16 \% .{ }^{14}$ I dette valget sto noe på spill. Konflikten fikk kirkemedlemmer ut av sofaen og inn i stemmelokalet. ${ }^{15}$

Begge de motstridende sidene i konflikten hevdet å representere sann kristendom. Det var ingen rasjonell løsning på konflikten. Konsensusorienterte prosesser, for eksempel i regi av Lærenemnda, var prøvd ut, men hadde ikke ført til noen nevneverdige resultater. Folk ble ikke enige selv om de snakket sammen i årevis. Isteden tilspisset konflikten seg, og hver av partene benyttet seg av storslagne retoriske og konflikts økende strategier for å tydeliggjøre forskjeller, mobilisere og framheve sin fortolkning som sann kristendom. Konflikten artet seg ikke som en veloverveid diskusjon, men som en følelsesladet kamp mellom ulike sannhetsfortolkninger som handlet om menneskers liv.

Etter at de som støttet kirkelig godkjenning av likekjønnet ekteskap, hadde fått flertall i Kirkemøtet, ble imidlertid ikke motstanderne ekskludert. I agonistisk teori er man opptatt av å artikulere felles symbolske rom som kan romme uenigheten. A innskrive konflikter i et felles symbolsk rom er avgjørende for at uenighetsfellesskapet skal forbli et fellesskap. Det innebærer at de motstridende partene anerkjenner hverandre som likeverdige medlemmer av fellesskapet til tross for sine meningsforskjeller. Man mobiliserer forskjeller og kjemper om 
hegemoni, men forblir i det symbolske fellesskapet. Dette er selvsagt krevende, og avhenger naturlig nok også av hva uenigheten dreier seg om. Et godt historisk eksempel på uenighet som ikke har blitt tålt i kirkelig sammenheng, er apartheidpraksisen til to kirker i det sørlige Afrika, som ble suspendert fra Det lutherske verdensforbund i 1984. ${ }^{16}$

Det symbolske rommet utgjør rammene for mangfoldet og differensierer mellom legitime og illegitime konflikter. Hva det symbolske fellesrommet er, er derimot ikke gitt, men noe det stadig kjempes om å definere. For Den norske kirkes del har kirkeforståelsen i CA 7 ofte fungert som den formelle normen og avgrensningen av det felles teologiske rommet. Kirkefellesskapet kan tåle ulike praksiser og teologisk og etisk mangfold så lenge evangeliet forkynnes rent og sakramentene forvaltes rett. Men hvordan evangeliet, forstått som meddelelsen av Guds løfter til mennesker, forstås i konkrete situasjoner, er et hermeneutisk anliggende, og dermed noe det også vil herske fortolkningsuenighet om. I 2007, da Kirkemøtet hadde åpnet opp for at de enkelte bispedømmerådene kunne bestemme hvorvidt de ville ansette homofilt samlevende prester eller ei, holdt fremdeles flertallet av biskoper og kirkerådsmedlemmer fast ved at aksept av likekjønnet ekteskap - til forskjell fra partnerskap ville være kirkesplittende, da dette ble ansett for nettopp å stride mot evangeliet. ${ }^{17}$ Men som kjent ble ikke likekjønnet ekteskap forstått som kirkesplittende av like mange noen år senere, fordi flertallet da tolket evangeliet annerledes. Dette er oppsiktsvekkende kort tid i et kirkehistorisk perspektiv, men samtidig illustrerende for hvilke kulturelle, hermeneutiske og politiske prosesser som alltid er i sving når det gjelder artikulering av det felles symbolske rommet og av hva som utløser status confessionis, hva som er adiafora, og hva som er kirkelig lære som sådan. ${ }^{18}$

Fra et agonistisk perspektiv har dermed konflikten om homofiles rettigheter i Den norske kirke for det første bidratt til inkludering av nye mennesker i kirken, til utvikling av ny lære og nye ritualer, og til involvering og $\varnothing \mathrm{kt}$ engasjement blant kirkens medlemmer. Men for det andre har den ført til reartikulering av spørsmål om apostolisitet og kirkelig enhet, blant annet ved å vise sammenhenger mellom makt, hegemoni og apostolisitet, og testet enhetens fleksibilitet.

\section{Konflikten(e) i det anglikanske kirkefellesskapet}

Den andre casen dreier seg også om konflikten rundt homofilt samliv, men innenfor det globale anglikanske kirkefellesskapet. Siden fellesskapet formelt ble dannet i 1864, har the 
Anglican Communion gjentatte ganger vært preget av konflikter og splittelser. ${ }^{19}$ I løpet av de siste tre tiårene har fellesskapet særlig vært utfordret av uenighet i synet på seksualitet og homofilt samliv. Debatten preget Lambeth-konferansen i 1998, men den eskalerte dramatisk da Gene Robinson ble konsekrert til biskop i Den episkopale kirken i USA i 2003. Han ble med det den første biskopen i det anglikanske kirkefellesskapet som levde åpent $\mathrm{i}$ et homofilt parforhold. Protestene fra mange anglikanske kirker i det globale sør var store, særlig i Uganda, Kenya, Sudan, Nigeria og på det søramerikanske kontinentet.

Eskaleringen av konflikten sammenfalt i tid med utgivelsen av Philip Jenkins' berømte bok The Next Christendom (2002). Jenkins er selv anglikaner, og boka ble raskt verdenskjent på grunn av påstanden om skiftet innen global kristendom: at flertallet av verdens kristne og med det også kristne maktsentra flytter seg fra det globale nord til det globale sør. ${ }^{20}$ Konflikten i det anglikanske kirkefellesskapet ble av flere tolket i rammen av Jenkins' bok. ${ }^{21}$ På den måten ble konflikten gjort til eksempel på nedgangen for sekularisert og liberal kristendom i nord og $\emptyset$ kningen for evangelikal og mer konservativ kristendom i det globale sør. Transnasjonale allianser mellom konservative og rike aktører i nord og noen kirker og kirkeledere i sør bidro til å nære konflikten. Med disse alliansene fikk konservative anglikanere i USA og Storbritannia, som hadde tapt kulturkampen i nord, sjansen til å slutte seg til «den globale kristendommens framtid»sammen med kristne i sør. De afrikanske kirkene på sin side, eller rettere sagt enkelte av deres kirkeledere, fikk ikke bare solid pengest Øtte, men også mer innflytelse i det verdensvide anglikanske kirkefellesskapet enn hva som hadde vært tilfelle tidligere.

Agonistisk teori er opptatt av at grenser og fronter er uunngåelige i kollektiv identitetskonstruksjon, samtidig som disse også er flyktige og komplekse. Derfor kan agonistisk teologi være et nyttig analytisk redskap til å studere hvordan grensedragninger og fronter fungerer i teologisk sammenheng, hva de produserer, og hvordan de mobiliseres retorisk i identitetskonflikter. I den globale anglikanske konflikten viser det seg for eksempel at grensene mellom nord og sør ikke har vært like entydige som man kan få inntrykk av. De anglikanske provinsene i det sørlige Afrika og i Sør-India var mer åpne for den nye praksisen enn kirkene i Nigeria, Kenya og Uganda. ${ }^{22}$ Og også i nord var det tydelige interne skiller mellom motstandere og forkjempere av Gene Robinson. Noen amerikanske menigheter og prester brøt med sin lokale biskop og søkte tilsyn hos konservative biskoper i andre anglikanske provinser. Andre steder brøt konservative allianser sammen nesten før de rakk å etablere seg: En varig og forpliktende relasjon mellom liturgisk høykirkelige amerikanere og 
karismatiske lavkirkelige nigerianere viste seg vanskelig, selv om de begge fordømte homofilt samliv. I tillegg var det også konservative biskoper i sør som hadde sterke humanitære og $\emptyset$ konomiske samarbeidsrelasjoner med liberale anglikanske institusjoner i nord, og som valgte å nedtone konflikten i det globale anglikanske kirkefellesskapet. Dette illustrerer at ekklesiologiske spørsmål og konflikter bør studeres fra forskjellige perspektiver. Teologi skjer alltid i skjæringspunktet mellom teologi, kultur, politikk og marked.

Forskeren Miranda Hassett har analysert kompleksiteten i de internasjonale anglikanske relasjonene og påpekt hvordan høyst ulike faktorer som økonomi, kultur, spiritualitet, liturgiske tradisjoner, kolonial historie, syn på familie og seksualitet ble forhandlet, og hvordan disse faktorene også påvirket diskursen om enhet i kirkefellesskapet. ${ }^{23}$ Den globale anglikanske konflikten er med andre ord svært sammensatt. Siden agonistisk teologi anerkjenner at teologiske fortolkninger er kontingente og også resultater av hegemoniske maktkamper, blir det vesentlig å lese konflikter med et maktkritisk blikk. Konflikten i det globale anglikanske kirkefellesskapet er tross alt også en konflikt hvor tidligere koloniserte kirker krever innflytelse, respekt og medbestemmelse i et fellesskap opprettet av kolonimakten. En måte å bedrive maktkritikk på er å spore differensieringsprosesser framfor å godta påstått essensialistiske forskjeller. ${ }^{24}$ Hvem blir satt opp mot hverandre? Hvem blir ekskludert, og hvem blir inkludert? Det er vanskelig å unngå differensiering i identitetsprosesser, men ved å anerkjenne differensieringsmekanismer, og fors $\emptyset \mathrm{ke} a ̊$ synliggjøre dem, kan en bidra til økt transparens og større bevissthet om dem. Forskjeller er alltid artikulert, utvalgt og retorisk vektlagt av noen. Hva konflikten dreier seg om, er alltid definert av noen, noe Ian Douglas minner oss om i sin anmeldelse av The Next Christendom:

If there is a crisis in world Christianity, it is not between an old Christendom of the West and a new Christendom of the South but rather between an hegemonic, monocultural expression of Western Christianity and an emerging, multicultural global Christian community embodying radical differences. The emergence of the diverse voices of Christianity in the global South is not "the next Christendom" but rather a new Pentecost. [...] God's ongoing intervention in the world is being made real in the many tongues and cultural realities of a new Pentecost. ${ }^{25}$

Kort sagt, det kommer an på blikket som ser.

En annen måte agonistisk-teologisk tenkning kan brukes på i denne konflikten er å problematisere, og dermed også bidra til, den teologiske diskursen om enhet. Hva er det 
egentlig som forener de ulike kirkene i det anglikanske kirkefellesskapet? Hva er global anglikansk kristendom i en postkolonial og desentrert verden? Markerer den pågående konflikten en splittelse i det globale kirkefellesskapet, eller viser den snarere at fellesskapet kanskje aldri var så tett og gjensidig? Kanskje viser konflikten at de ulike kirkene ikke har så mye til felles som en først trodde? For hva deler de egentlig, bortsett fra en formell troskap til erkebiskopen av Canterbury og liturgiske tradisjoner som knytter seg til The Book of Common Prayer? Kontroversen om homofilt samliv har åpenbart vært krevende for enhetsarbeidet i det anglikanske kirkefellesskapet. Men samtidig har den også intensivert artikuleringen av, insisteringen på, søken etter og bønn om kirkelig enhet. ${ }^{26}$

\section{Konflikt og hellighet}

Hva så med helligheten? Hvis kirken er hellig, kan den da romme konflikter? Å peke på produktive sider ved uenighet er ikke det samme som å omfavne destruktive krangler. I det anglikanske kirkefellesskapet har det haglet med anklager og harde ukvemsord mellom ulike aktører. Den liberale amerikanske biskopen John Shelby Spong uttalte for eksempel følgende forut for Lambeth-konferansen i 1998: «African Christians are superstitious fundamentalists who have moved out of animism into a very superstitious kind of Christianity, and have yet to face the intellectual revolution of Copernicus and Einstein that we have had to face in the developing world.» ${ }^{27}$ Dette utsagnet ville vi i dag kalt rasistisk. Men kraftsalvene gikk begge veier. Den nigerianske erkebiskopen Peter Akinola fordømte Gene Robinson og sa at den episkopale kirken i USA var «a cancerous lump in the Anglican body that should be excised». ${ }^{28}$

Ingen av disse utsagnene er særlig hellige, men Akinolas anklage er i det minste interessant $\mathrm{i}$ én forstand: kreftmetaforen - retorikken om at noe er sykt og må fjernes fra det ellers friske legemet. Et slikt syn på konflikt gjenspeiler langt på vei retorikken i Windsor-rapporten, en offisiell anglikansk rapport fra 2004 som gransket problemene i det anglikanske kirkefellesskapet som følge av konsekreringen av Gene Robinson. Rapporten beskriver konflikten i det anglikanske kirkefellesskapet delvis som sykdom, og delvis som synd. ${ }^{29}$ Ifølge en slik tankegang er konflikt et avvik fra det tidligere sunne og hellige kirkelegemet. Kyle Lambelet har hevdet at ekklesiologier som betoner kirken som et hellig folk, ofte har en tilnærming hvor konflikt forstås som nettopp synd. Enten bør konflikten overvinnes eller ryddes av veien - den er motsatsen til den ontologiske freden som konstituerer kirken -, eller 
så er konflikten usann i teologisk forstand. Den eksisterer egentlig ikke i den sanne kirke, fordi Guds folk ikke kan være et konfliktens folk. ${ }^{30}$

Fra et agonistisk perspektiv gir slike ekklesiologiske forestillinger liten mening. En kan simpelthen spørre hvordan en slik ekklesiologi kommer til rette med de utallige eksemplene på konflikter i kirkens historie. Slike holdninger gjør det tydelig at det er et behov for å teologisere og symbolisere konflikter annerledes, og anerkjenne at uenighet er en integrert del av det å være en hellig kirke. Ikke for å romantisere konflikt, eller for å applaudere uhøflighet, men for bedre å kunne kvalifisere og forholde seg til konflikter. Så kan en lete etter måter å leve i og med konflikt på som kan være konstruktive, og kanskje til og med øve seg på å lete etter spor av Den treenige Gud i fortolkningskonfliktene. Kanskje nettopp kunsten å leve i og med uenighet er det som viser kirkens hellighet?

\section{Enhet i uforsonet mangfold?}

I den siste casen zoomer jeg ut til det bredeste kirkefellesskapet i verden, og ser på diskursen om enhet og katolisitet i den økumeniske bevegelsen. Kirkenes Verdensråd (KV) ble grunnlagt i en tid da store deler av verden lå i ruiner etter andre verdenskrig. Enhetsarbeid, også mellom kirker, var viktigere enn noen gang. På KVs første generalforsamling i Amsterdam i 1948 samlet organisasjonen seg om slagordet «We intend to stay together». ${ }^{31}$ Fram til 1970-tallet var målet til den økumeniske bevegelsen organisk enhet («organic unity») mellom kristne. Erklæringen om kirkens enhet fra KVs tredje generalforsamling i New Delhi i 1961 uttrykker det på følgende karakteristiske vis:

We believe that the unity which is both God's will and his gift to his Church is being made visible as all in each place who are baptized into Jesus Christ and confess him as Lord and Saviour are brought by the Holy Spirit into one fully committed fellowship, [...] joining in common prayer, and having a corporate life. ${ }^{32}$

Tanken om at alle kristne på ett og samme sted skulle leve og be sammen, var blant annet inspirert av den nydannede kirken Church of South India, som var resultatet av en sammenslåing av ulike anglikanske, presbyterianske og metodistiske kirker i India. Den nye organisatoriske enheten ble til og med forklart med referanser til påskedramaet: «Christians had to die to divisive identities and rise to the new life of the unity willed by Christ for his church.» ${ }^{33}$ 
Forestillingen om at alle kristne på ett og samme sted skulle fortolke og praktisere kristendom på samme måte, er hva Kathryn Tanner kritisk omtaler som «situationalism». ${ }^{34}$ I sin kritikk av postliberal teologi argumenterer Tanner for at mangfold ikke primært er en funksjon av kontekst og dermed ikke utelukkende kan forklares ut fra ulike situasjoner. På ett og samme sted vil det oppstå et mangfold av ulike kristne fortolkninger og praksiser, hevder Tanner, fordi det kristne symboluniverset og den kristne kanon i seg selv er så mangfoldig og rommer så mange ulike og motstridende stemmer. De kristne symbolene foreskriver ikke én spesifikk fortolkning. Ulike og rivaliserende fortolkninger er en nødvendighet både mellom og innad i kirkesamfunn, hevder Tanner.

Institusjonell enhet viste seg å ikke være like realistisk som mange først hadde håpet på. Fra begynnelsen av 1970-tallet oppstår det dermed en ny og mer nøktern visjon i den økumeniske bevegelsen: enhet i forsonet mangfold («unity in reconciled diversity»). Innenfor denne tankemodellen ble den mangfoldige konfesjonelle arven i større grad enn tidligere anerkjent og verdsatt. En Faith and Order-rapport fra 1984 er et godt eksempel på dette, hvor det heter at «the truth of the one faith seeks a great variety of forms of expression in history». ${ }^{35}$ Dette reflekterer en forståelse av forholdet mellom enhet og mangfold hvor ulikhet i større grad enn tidligere blir anerkjent og verdsatt. Enhet er fremdeles noe en søker innenfor en slik forståelseshorisont, men ikke i organisatorisk eller konfesjonell forstand. Enheten er forstått som en enhet av tidligere splittede, men fremdeles forskjellige kirker som nå lever i et gjensidig forpliktende fellesskap og deler felles tro og oppdrag i verden. Karakteristisk nok fokuserte Kirkenes Verdensråds generalforsamling i 2013 på «We intend to move together», ikke på «We intend to stay together», slik den gjorde i $1948 .{ }^{36}$

Dette betyr imidlertid ikke at katolisitetsproblemet er løst i det nye enhetsparadigmet. I mange $\varnothing$ kumeniske miljøer er unity in reconciled diversity fremdeles forstått som noe en kan oppnå, om enn gradvis, og videre som et steg mot en større og mer substansiell enhet. Ordet «forsonet» («reconciled») forstås ofte i retning av fortolkningsmessig konvergens. Forventningen om et slikt økumenisk framtidig mål har kraft i seg til å skape håp så vel som knuste forhåpninger. Et typisk eksempel på forventningen og håpet om økt teologisk konvergens finner en i det $\varnothing$ kumeniske dokumentet Charta Ecumenica. Dette ble lansert i 2001 av protestantiske, ortodokse og katolske kirker i Europa. I åpningsparagrafen forplikter de ulike kirkene seg på å «persevere in seeking a common understanding of Christ's message of salvation in the Gospel».37 Men hvorfor er en felles forståelse av frelsesbudskapet $\emptyset$ nskelig? Hva oppnår en egentlig med formuleringer som uttrykker enighet om frelsen? Er 
ikke det en redusering av frelsesmysteriet? Hvorfor feirer en ikke heller

fortolkningsforskjellene? De utgjør tross alt en rikdom som er med på å gjøre frelsesmysteriet større. Ville det ikke vært en større bragd å søke etter enhet i uforsont mangfold, det vil si et mangfold som ikke nødvendigvis konvergerer eller går logisk opp? Det ville ikke bare utvidet fortolkningsrommet og hindret det $\mathrm{i}$ å lukke seg, men det kunne også framprovosert mer djerve og interessante teologiske fortolkninger. For å si det med Stephen Sykes’ ord: «A formal definition [of Christianity] is both banal and boring. Christianity only becomes interesting as a concept when someone has the courage to spell out in greater or lesser detail one or other of the contestable possibilities which the definition permits.» ${ }^{38}$

Kirkelig enhetsarbeid trenger verken å ha som mål institusjonell enhet eller teologisk konvergens for at verden skal tro. Det er mer enn viktig nok som et arbeid som kontinuerlig artikulerer, leter etter og insisterer på enheten som faktisk er gitt kirken, til tross for alle forskjellene og (uforsonte) uenigheter som finnes.

\section{Konflikt og inkludering av nye grupper}

I ekklesiologiske tekster refereres det rett som det er til Apostlenes gjerninger, kapittel 2 når fellesskapet mellom de første kristne beskrives. Der kan en lese om menigheten i Jerusalem, som «holdt seg trofast til apostlenes lære og fellesskapet, til brødsbrytelsen og bønnene. [... A Alle de troende holdt sammen og hadde alt felles». ${ }^{39}$ Det er ingenting å utsette på å lære, spise og be sammen, men det som overses i disse forsøkene på å artikulere en bibelsk forankret ekklesiologi, er uenigheten i Jerusalem-menigheten noen kapitler senere. I kapitel 15 kan en nemlig lese om den sterke uenigheten som preger menigheten i spørsmålet om hedningenes status. En krangel bryter ut mellom medlemmene av menigheten, selv mellom Peter og Paulus, om hvorvidt hedningene skal inkluderes eller ikke. Troen på at Guds kjærlighet omfattet alle mennesker viste seg å forårsake høylytt konflikt. Kyle Lambelet har argumentert for at konflikt i denne konkrete situasjonen var utslagsgivende for at den tidlige kirken skulle forstå nettopp Guds radikale kjærlighet. ${ }^{40}$ Det var konflikt som genererte den nye innsikten. Konflikt var nødvendig for å skape endring og transformasjon. Og dette var heller ikke den siste konflikten i kirkehistorien som resulterte i en mer inkluderende kirke.

Minnet om fortiden vi deler som kirke, peker ikke i retning av at konflikt og uenighet ikke har forekommet. Snarere tvert imot. Det hjelper oss heller til å forstå og godta at konflikt er en sentral del av kirkens historie, ja av hva det vil si å være en offentlighet, en ekklesia. Uenighet og fortolkningskonflikter synes å være normaltilstanden for kirken i historien, helt fra det 
apostoliske fellesskapet slik det er beskrevet i Apostlenes gjerninger, til

kirkefedrekontroversene, de økumeniske konsilene, reformasjonene og fram til i dag.

Jeg mener at agonistisk teologi på denne måten kan bidra til det økumeniske fellesskapet ved å problematisere og nytenke kirkens vesensbestemmelser (esse). Et agonistisk perspektiv kritiserer troen på at kristendom fortolkes likt av mennesker i samme kontekst (situationalism). Det insisterer på at kirkefellesskap (communio) ikke er fritt for konflikter, men et sted hvor konflikter og uenighet får utspille seg. Det insisterer på at enhet verken er et resultat av enighet eller en tilstand uten sterke og delvis internt motstridende påstander. Agonistisk teologi minner om at økumeniske møter ikke er møter mellom homogene eller tydelig avgrensede fellesskap, men snarere mellom internt mangfoldige og heterogene grupper. Slik understreker agonistisk teologi også at kirkefellesskapene er bygd på kontingente grenser som har blitt vektlagt og fortolket ulikt til forskjellige tider. Kanskje kan det også bidra til nye identitetskonstruksjoner og fellesskap som er konstituert langs andre grenselinjer - for eksempel grenser som oppleves som viktigere enn konfesjonell tilhørighet i dagens virkelighet?

\section{En stemme blant flere}

I denne artikkelen har jeg brukt konseptet agonistisk teologi dels som et analytisk perspektiv og dels som et normativt argument og med det vist, ved hjelp av tre caser, hvordan agonistisk teologi kan bidra konstruktivt til ekklesiologisk refleksjon. Med det sier jeg ikke at konflikt og uenighet alltid bare er bra. Agonistisk teologi er et perspektiv, en kritikk, en - kanskje omstridt? - stemme blant flere. Dette perspektivet, eller kritikken, kan forhåpentligvis lære oss noe om uenighet, og kanskje sette oss bedre i stand til å håndtere uenighet. Kanskje kan vi også, som Jakob, erfare at ut av en kamp kan det komme velsignelse.

\footnotetext{
Noter

${ }^{1}$ Sven Thore Kloster, Towards an Agonistic Theology: A Political Reading of the Concepts of Tradition in the Christian Theologies of Gerhard Ebeling and Kathryn Tanner (ph.d.-avhandling ved Universitetet i Oslo, 2020). Denne artikkelen er en bearbeidet versjon av prøveforelesningen jeg holdt forut for min disputas 13.2.2020. 2 Se f.eks. Chantal Mouffe, The Democratic Paradox (London: Verso, 2000), 102-3, og On the Political (London: Routledge, 2005), 20.

${ }^{3}$ Noen eksempler fra den engelskspråklige sfære er Mark Lewis Taylor, The Theological and the Political: On the Weight of the World (Minneapolis: Augsburg Fortress, 2011); Kristen Deede Johnson, Theology, Political Theory and Pluralism: Beyond Tolerance and Difference (Cambridge: Cambridge University Press, 2007); Charles T. Mathewes, "Faith, Hope, and Agony: Christian Political Participation beyond Liberalism», The Annual of the Society of Christian Ethics 21 (2001): 125-50, DOI: https://doi.org/10.5840/asce2001219.
} 


\footnotetext{
${ }^{4}$ På engelsk skriver jeg «community of conflict», «community of disagreement» eller «community of contestation». Det norske ordet «uenighetsfellesskap» er lånt av Lars Laird Iversen, se Lars Laird Iversen, Uenighetsfellesskap: Blikk på demokratisk samhandling (Oslo: Universitetsforlaget, 2014).

${ }^{5}$ Alister E. McGrath, The Genesis of Doctrine: A Study in the Foundations of Doctrinal Criticism

(Oxford/Cambridge, MA: Blackwell, 1990), 3.

${ }^{6}$ Alasdair McIntyre, «Epistemological Crises, Dramatic Narrative and the Philosophy of Science», The Monist 60 (1977): 453-72 (460), DOI: https://doi.org/10.5840/monist197760427.

${ }^{7}$ Se Sergey Dolgopolski, What is Talmud? The Art of Disagreement (New York: Fordham University Press, 2009).

${ }^{8}$ Chantal Mouffe, The Democratic Paradox, On the Political, The Return of the Political (London: Verso, 1993) og Agonistics: Thinking the World Politically (London: Verso, 2013).

${ }^{9}$ Kathryn Tanner, Theories of Culture: A New Agenda for Theology (Minneapolis: Augsburg Fortress, 1997), 154.

${ }^{10}$ I tillegg til min ph.d.-avhandling Towards an Agonistic Theology (se n. 1) gir jeg et teoretisk bidrag til agonistisk teologi i Sven Thore Kloster, «Community of Conflict: Towards an Agonistic Theology with Chantal Mouffe and Kathryn Tanner», i The Reformation of Philosophy: The Philosophical Legacy of the Reformation Reconsidered (red. M. Mjaaland; Tübingen: Mohr Siebeck, 2020), 241-58.

${ }^{11}$ Kathryn Tanner, "Tradition and Theological Judgment in Light of Postmodern Cultural Criticism», i Tradition and Tradition Theories: An International Discussion (red. T. Larbig og S. Wiedenhofer; Berlin: LIT Verlag, 2006), 229-46; "Postmodern Challenges to 'Tradition'», Louvain Studies 28 (2003): 175-93, DOI: https://doi.org/10.2143/ls.28.3.504305, og Theories of Culture.
}

${ }^{12}$ Michel Foucault, «Nietzsche, Genealogy, History», i The Foucault Reader (red. P. Rabinow; Harmondsworth: Penguin, 1986), 76-100.

${ }^{13}$ Niels Henrik Gregersen, «Dogmatik som samtidsteologi», Dansk Teologisk Tidsskrift 71 (2008): 290-310 (309).

${ }^{14}$ https://kirken.no/nb-NO/om-kirken/aktuelt/rekordvalg-i-kirken/ (lest 10.2.2020).

${ }^{15}$ Se f.eks. Sunniva E. Holberg, Bjarke S. Mortensen, Pål K. Botvar, Polarisering og kontinuitet: En analyse av kirkevalget i 2015 (Oslo: KIFO, 2016) og Knut A. Rydjord, «Et nytt lekfolk», Kirke og Kultur 120 (2016): 89-98, DOI: https://doi.org/10.18261/issn.1504-3002-2016-01-10.

${ }^{16}$ Peter Lodberg, «Apartheid as a Church-Dividing Ethical Issue», The Ecumenical Review 48 (1996): 173-77, DOI: https://doi.org/10.1111/j.1758-6623.1996.tb03462.x. For en ytterligere diskusjon om apartheid og kirkeskisma, se Neville Richardson, "Apartheid, Heresy, and the Church in South Africa», The Journal of Religious Ethics 14 (1986): 1-21.

${ }^{17}$ Se biskopenes utredning i 1997: «Kirkens enhet og troens fundamenter: Innstilling til Bispemøtet», https://kirken.no/nb-NO/om-kirken/slik-styres-kirken/bispemotet/om-

oss/dokumenter/Protokoller/bispemotet-02.10.1997---08.10.1997-oslo/ (lest 3.5.2020). Samtlige biskoper avviste likekjønnet ekteskap så sent som i oktober 2004. Kun to biskoper (Fiske og Jørgensen) var positive til kjønnsnøytral ekteskapslov i 2007.

${ }^{18}$ For et interessant og relatert innspill om kirkelig lære, se Jan-Olav Henriksen, «Hva er lære? Et religionsteoretisk innspill til et gammelt problem med aktuell relevans», Teologisk tidsskrift 5 (2016): 358-76, DOI: https://doi.org/10.18261/issn.1893-0271-2016-04-07.

${ }^{19}$ Duane Alexander Miller, «The Bricolage of Global Anglicanism: Holy Trinity Anglican Church, San Antonio», Anglican and Episcopal History 83 (2014): 67-73.

${ }^{20}$ Philip Jenkins, The Next Christendom: The Coming of Global Christianity (Oxford: Oxford University Press, 2002).

${ }^{21}$ Se f.eks. Alister McGrath, «A Lecture to the 'Future of Anglicanism' Conference, Oxford, UK» fra 8. juli 2002, www.americananglican.org (lest 15.1.2020).

22 Jeg baserer analysen min om konflikten i the Anglican Communion på Miranda K. Hassett, Anglican Communion in Crisis: How Episcopal Dissidents and their African Allies are Reshaping Anglicanism (Princeton og Oxford: Princeton University Press, 2007).

${ }^{23}$ Ibid.

${ }^{24}$ Se f.eks. Judith Gruber, Intercultural Theology: Exploring World Christianity after the Cultural Turn (Göttingen: Vandenhoeck \& Ruprecht, 2018).

${ }^{25}$ lan Douglas, «Book Review: The Next Christendom», The World \& I (2003), referert til i Hasset, Anglican Communion in Crisis, 258.

${ }^{26}$ Et eksempel på dette er Bruce N. Kaye, Conflict and the Practice of Christian Faith: The Anglican Experiment (Cambridge: Lutterworth Press, 2011). 
${ }^{27}$ Andrew Carey, "African Christians? They're Just a Step up from Witchcraft», Church of England Newspaper, 10. juli 1998, referert til i Hassett, Anglican Communion in Crisis, 72.

${ }^{28}$ Peter Akinola sitert i «Nigeria Bishops Scorn US 'Cancer'», BBC News, 4. juli 2006, http://news.bbc.co.uk/2/hi/africa/5144036.stm (lest 5.2.2020).

${ }^{29}$ The Lambeth Commission on Communion, «The Windsor Report» (London: The Anglican Communion Office, 2004), se særlig paragrafene 22-42, https://www.anglicancommunion.org/media/68225/windsor2004full.pdf (lest 3.2.2020).

${ }^{30}$ Eksempler på slike tilnærminger finnes blant annet i forfatterskapet til John Milbank, se «Postmodern Critical Augustinianism: A Short Summa in Forty-Two Responses to Unasked Questions» i The Postmodern God: A Theological Reader (red. G. Ward; Oxford: Blackwell, 1997), og John Webster, se «Theology and the Peace of the Church", i The Domain of the Word: Scripture and Theological Reason (London: T \& T Clark, 2012). Kyle Lambelet skriver utfyllende om denne tematikken i Kyle B.T. Lambelet, «Conflict as Communion: Towards an Agonistic Ecclesiology», Journal of Anglican Studies 17 (2019): 133-47, DOI:

https://doi.org/10.1017/s1740355319000135.

${ }^{31}$ The Message of the 1st Assembly of the World Council of Churches (1948),

https://www.oikoumene.org/en/resources/documents/assembly/1948-amsterdam/a-message-to-all-christianpeople (lest 2.2.2020).

32 World Council of Churches, «New Delhi Statement on Unity», 1961, paragraf 2,

https://www.oikoumene.org/en/resources/documents/assembly/1961-new-delhi/new-delhi-statement-onunity (lest 2.2.2020).

${ }_{33}$ David Carter, «Unity in reconciled diversity: Cop-out or rainbow Church?», Theology 113 (2010): 411-20 (411), DOI: https://doi.org/10.1177/0040571×1011300603.

${ }^{34}$ Tanner, Theories of Culture, 158-59.

${ }^{35}$ Se Faith and Order, «The Unity of the Church and the Renewal of Human Community: Programme Outline», The Ecumenical Review 36 (1984): 323-29 (325).

${ }^{36}$ Message of the 10th WCC Assembly (2013), paragraf 6,

https://www.oikoumene.org/en/resources/documents/assembly/2013-busan/adopted-documentsstatements/message-of-the-wcc-10th-assembly (lest 2.2.2020).

${ }^{37}$ Conference of European Churches (CEC) og the Roman Catholic Council of European Bishops' Conferences (CCEE), Charta Oecumenica (2001), paragraf 1, side 4, http://www.ceceurope.org/wpcontent/uploads/2015/07/ChartaOecumenica.pdf (lest 8.2.2020).

${ }^{38}$ Stephen Sykes, The Identity of Christianity: Theologians and the Essence of Christianity from Schleiermacher to Barth (London: SPCK, 1984), 256.

${ }^{39}$ Apostlenes gjerninger kap. 2, vers 42 og 44 .

${ }^{40}$ Lambelet, "Conflict as Communion». 